症例

\title{
胃切除後早期に発症した急性気腫性胆囊炎の 1 例
}

\author{
東京都立広尾病院外科
}

阿 部秀 樹 若山達 郎 奥山正治豊田忠之

急性気腫性胆震炎の 1 例を報告するとともに, 本邦報告96例を集計し若干の考察を加 えた。

症例は63歳の男性で, 胃切除後第12病日に発症した. 腹部単純 X 線撮影で右助弓下に

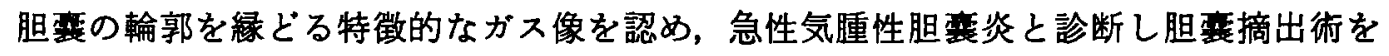
行った. またその 1 年後の胆道造影で総胆管内に結石を認め, これを経皮経肝的, 内視 鏡的に切石した。

本症の本邦報告96例中胃手術後の発症は11例あり，5ち術後早期の発症は 3 例である. $\mathrm{TAE}$ 施行後の発症は 3 例あり，すへてて施行後早期の発症である。またこれら96例中12例 の経過中に総胆管結石が認められている。

索引用語：急性気尰性胆要炎, 胃切除後, 総胆管結石

はじめに

急性気腫性胆覀炎は文献的検索の範囲内で本邦報告 例が96例を数える.今回この1例を経験したので文献 的考察を加えて報告する.

$$
\text { 症例 }
$$

患者：63歳, 男性.

主訴: 呕気, 心窩部痛, 背部痛.

家族歴，既往歴：特記すべきことなし。

現病歴: 平成 1 年 1 月 20 日早期胃癌の診断で 4 分の 3 胃切除, R2 2 ンパ節郭清, Billroth II 法再建を施行 した。術後早期の経過は順調であったが，1月27日 Winslow 孔ドレーンから胆汁の排液を認め, 以後これ が続いた，1月28日の上部消化管造影で胃空腸吻合か ら造影剂の漏れは無く，十二指腸断端の破裂を疑い絶 食, 中心静脈栄養とした。2 月 1 日上記主訴が出現し た。

術前現症：体温37.6度，血区110/74，脈拍90/分整。 負血, 黄㾝は認めなかった。腹部は右季肋部から㑡腹 部にかけて強い圧痛を認めた。

術前検查所見：白血球增多，T-Bil，ALP， LAP， $\gamma$-GTP，GOP，GPT の軽度上昇を認めた（表 1 ）。

腹部超音波検査： 2 月 2 日肋間走查で胆黄床に一致 して始まる strong echoを認め, 胆軣内腔は認められ なかった（図 1)。また右側腹の王痛部に echo free
表 1 術前(平成 1 年 2 月 4 日) 検查成綨

\begin{tabular}{clc}
\hline 血算 & WBC & $12600 / \mu \mathrm{l}$ \\
& $\mathrm{RBC}$ & 329 万 $/ \mu \mathrm{l}$ \\
& $\mathrm{Hb}$ & $10.0 \mathrm{~g} / \mathrm{dl}$ \\
$\mathrm{Ht}$ & $31.2 \%$ \\
& $\mathrm{Plt}$ & 44 万 6 千 $/ \mu \mathrm{l}$ \\
生化 & $\mathrm{GOT}$ & $70 \mathrm{IU} / 1$ \\
& $\mathrm{GPT}$ & $36 \mathrm{IU} / 1$ \\
$\mathrm{CK}$ & $440 \mathrm{IU} / 1$ \\
$\mathrm{AMY}$ & $155 \mathrm{IU} / 1$ \\
$\mathrm{~T}-\mathrm{Bil}$ & $0.4 \mathrm{mg} / \mathrm{dl}$ \\
$\mathrm{D}-\mathrm{BiI}$ & $0.3 \mathrm{mg} / \mathrm{dl}$ \\
$\mathrm{ALP}$ & $10.9 \mathrm{KAU}$ \\
$\mathrm{LAP}$ & $69 \mathrm{IU} / 1$ \\
& rGTP & $37 \mathrm{IU} / 1$ \\
\hline
\end{tabular}

白血球增多，T-Bil, ALP, LAP, $\gamma$-GTP, GOT, GPT の軽度上昇。

space を認め針穿刺にて胆汁が吸引された。

腹部単純 $\mathrm{X}$ 線検查： 2 月 3 日仰臥位にて抾張した 胆襄の輪郭を描くガス像を認めた（図 2).

腹部 CT 検查： 2 月 3 日壁内全周にガスを認め, 内 腔のガスが鏡面像を形成した。周囲にもガスはあった がドレーンのため評価できなかった（図 3 ）.

以上の検査から術後急性気腫性胆震炎, 胆汁性腹膜 炎と診断し， 2 月 4 日緊急手術を施行した。

手術所見：胆露はやや㗨满し赤色，灰白色，褐色， 黒色などブチ状の変色を呈し，一部に緑色の膿苔の付 


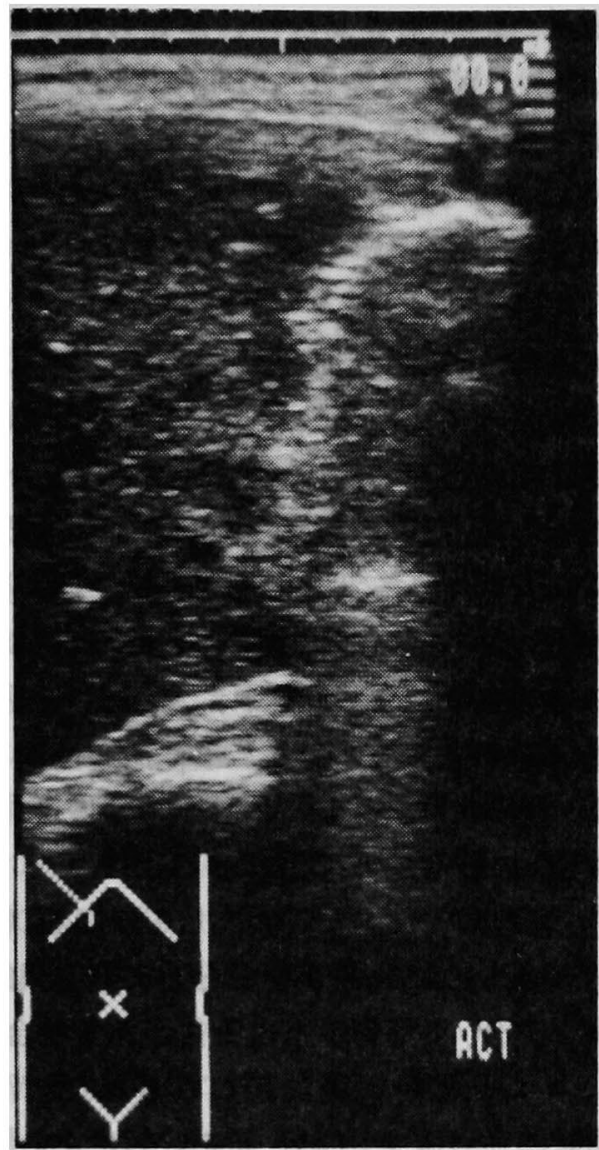

図 1 腹部超音波検査：胆撉床に一致して始まる storong echoを認める。

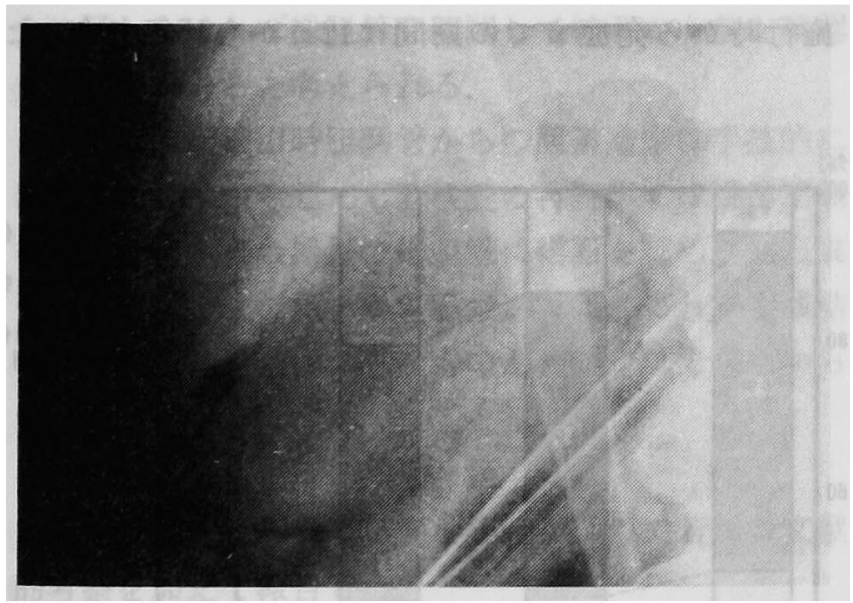

图 2 腹部単純 $\mathrm{X}$ 線検查：胆整の輪郭を描くガス像 を認める。

着を認めた。壊疽性の胆辜壁に穿孔は認めないが，浆 膜面から胆汁の唚出を確認した，胆変床部より摘出を 始め, 肝十二指腸勒帯付近では瘾着が強固で, 胆䓰頸 部全層を結禁切離し胆對を摘出した。十二指腸断端に 縫合不全はなかった。

標本所見：粘膜面は黒く壊疽性で，王迫すると割断

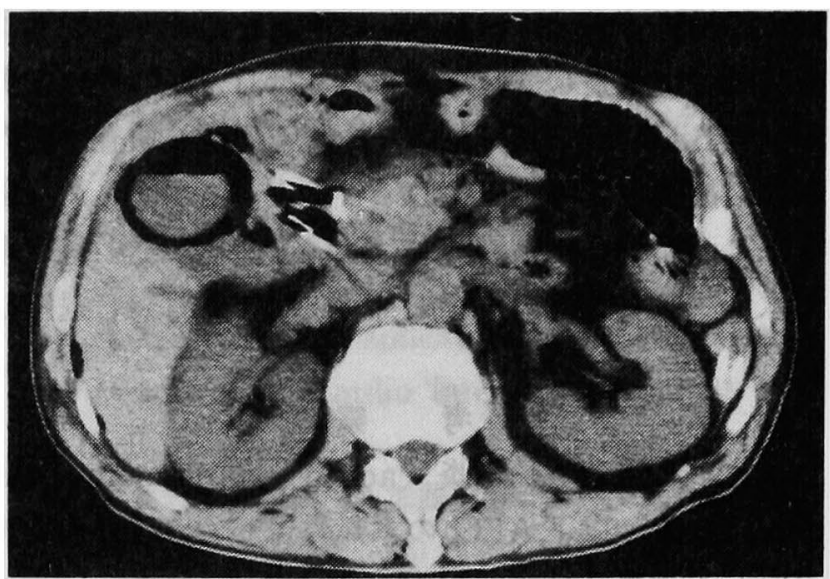

図 3 腹部 CT 検查：胆衰内腔, 壁内にガスを認める。

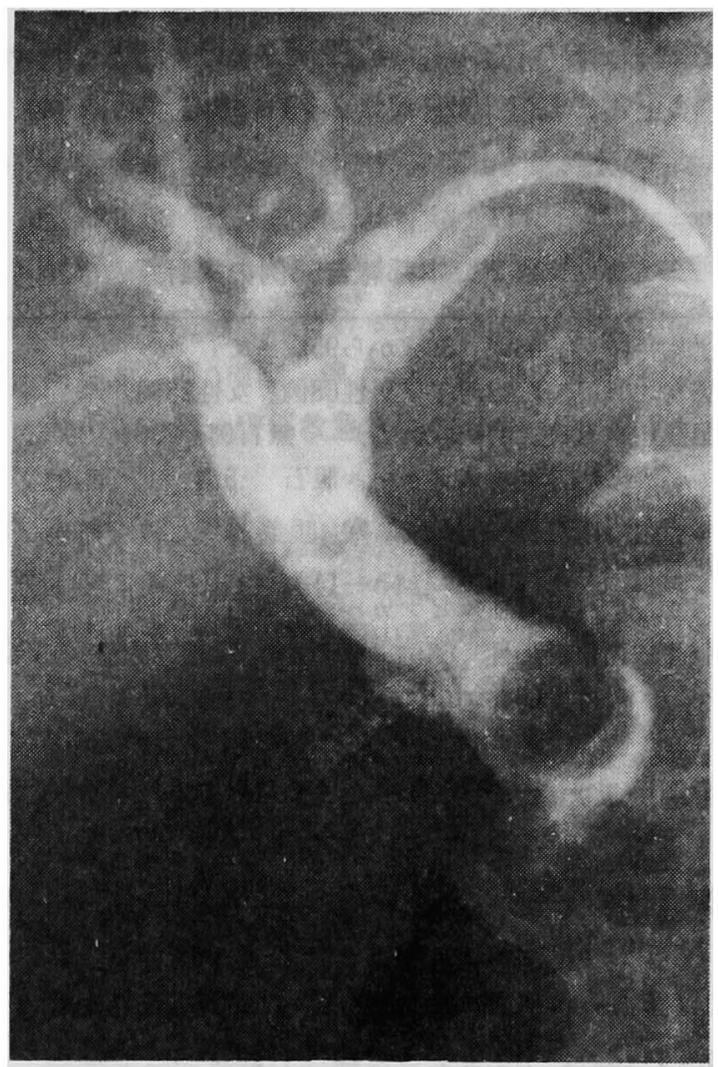

図 4 経皮経肝胆道造影：総胆管末端に径 $15 \mathrm{~mm}$ の 結石を認める。

面より泡を認めた。内腔に結石は認めず，胆汁培養に て Entreobacter aerogens が検出された。

術後経過：胆郦炎としての経過は順調だったが，ド レーンの機械的刺激が原因と考克られる横行結腸右側 から皮虚へ開口する瘦孔が牫った。平成 1 年 7 月 10 日 開腹，瘦孔閉鎖手術を施行したが術後も便汁の排出は 止まらず，12月 4 日外来通院とした。

平成 2 年 1 月 8 日食欲不振, 上腹部痛, 背部痛があ り再入院した。腹部 CT 検查, 経口性経静脈性胆道造 
影にて総胆管末端に径 $15 \mathrm{~mm}$ の結石を認め, 総胆管は 径 $17 \mathrm{~mm}$ に拡張していた。 2 月 9 日37.7度の発熱と黄 疸 (T-Bil $8.0 \mathrm{mg} / \mathrm{dl}$ ) があり, 腹部超音波検査で肝内 胆管の拡張を認め，PTCD カテーテルを挿入した（図 4 ).この瘦管を㹡張後, 経皮経肝的内視鏡的切石法(電 気水王式胆石破碎術）を施行し, 同年 4 月 14 日退院し た。

\section{考察}

急性気腫性胆资 (acute emphysematous

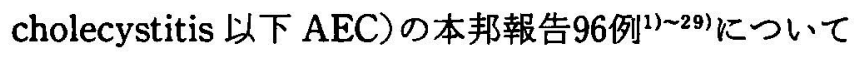
集計した（表 2).

(1) AECのガス像と発症からの経過時間

AEC の単純撮影上のガス像は発症からの時期に よって特徵的な次の 4 つの段階，（1）早期（24－48時 間）は正常，(2）内腔ガス，(3）壁内ガス，(4）周囲

\section{表 2 本邦報告96例の集計}

\begin{tabular}{|c|c|c|}
\hline 平均年龄 & \multicolumn{2}{|c|}{ 68歳（39歳から95藏まで） } \\
\hline 男女比 & \multicolumn{2}{|c|}{2.42 対 1 （男性68例 女性28例） } \\
\hline \multicolumn{3}{|c|}{ 胆震内有石例 44例（61\%） } \\
\hline \multicolumn{3}{|c|}{ コレステロール胆石 5 例 } \\
\hline \multicolumn{3}{|c|}{ 色素胆石 } \\
\hline \multicolumn{3}{|c|}{ 総胆管内有石例 12例 } \\
\hline \multicolumn{3}{|c|}{ ビリルビンカルシウム石 2 例 } \\
\hline \multicolumn{3}{|c|}{ 胆汁細菌培皦陽性 63 例（85\%）陰性 12 例（15\%） } \\
\hline \multicolumn{3}{|c|}{ Clostridium $\quad 25$ 例 $(40 \%)$} \\
\hline \multicolumn{3}{|r|}{ 12例（19\%） } \\
\hline \multicolumn{3}{|c|}{ Klebsiella $\quad$ 11例 $(17 \%)$} \\
\hline \multicolumn{3}{|c|}{ その他 ～24例（38\%） } \\
\hline \multicolumn{3}{|c|}{ 検出菌不明２1例 } \\
\hline \multirow[t]{4}{*}{ 手術施行 } & \multicolumn{2}{|c|}{81 例 $(90 \%)$ 非手術 9 例 $(10 \%)$} \\
\hline & \multicolumn{2}{|c|}{ 胆垔摘出術６4例（79\%） } \\
\hline & 胆裂外擕造設術 & 12例（15\%） \\
\hline & 術式不明 & 5 例 \\
\hline \multicolumn{3}{|c|}{ CT上のカス像による分類（施行39例について） } \\
\hline & 内腔ガス & 30 例 $(77 \%)$ \\
\hline & 壁内カス & 27 例 $(69 \%)$ \\
\hline & 周囲ガス & 10 例 $(26 \%)$ \\
\hline & 胆管内ガス & 2例 (5.1\%) \\
\hline & 局在不明 & 2例 \\
\hline \multicolumn{3}{|c|}{ 既往歴（記載67例について） } \\
\hline & 糖尿病 & 23例（34\%） \\
\hline & 高血圧 & 17 例 (25\%) \\
\hline & 脳血管障害 & 5 例 $(7.5 \%)$ \\
\hline & 冠血管障害 & 4 例 $(6.0 \%)$ \\
\hline & 胃手術後 & 10例（15\%） \\
\hline & TAE 施行後 & 3 例 $(4.5 \%)$ \\
\hline
\end{tabular}

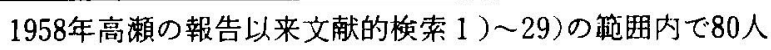
の報告ををとめた．
組織内ガス，に区別できることが知られている300 -33) （ただし壁内ガスと内腔ガスの順序については異なる 記載が見られる)。そこで本邦例中腹部 CT 検查を施行 した39例について見たが，CT 上のガスの局在と発症 からの時期の間に一定の傾向は見られなかった（図 5 ).

\section{（2） AEC と術後胆需炎}

術後胆要炎は術後の発熱, イレゥス, 創部痛によっ て症状が不明瞭となるが34), 吻合部縫合不全, 十二指腸 断端の縫合不全, 腹腔内膿煌, 腹膜炎 ${ }^{35)}$ との鑑別には超 音波検查が有用である。ところが㭪後早期に発症した AEC である本例では，肝下面の strong echo が腸管ガ スによる多重エコーと判断され，まず十二指腸断端の 縫合不全と診断された。そして単純撮影後はじめて胆 衰病変が明らかになった。

\section{（3）AEC の既往歴と病因}

AEC の病因の一次的な要因としては胆石，糖尿病， 血管病変があり，二次的な要因として非特異的な細菌 感染がある ${ }^{30136)}$. た胃手術の既往がある場合，迷走神 経切離やリンパ節郭清後に起こる濃厚な胆汁のうっ 滞, 胆裹壁の血行障害, Oddi 筋の収縮に上る膵液の胆 变内逆流, 胆道内圧の上昇 ${ }^{37)}$ も一次的な要因として考 学らる。

本邦96例中胃手術後の発症である11例133 -5127) 299 の 施行時から発症までの期間は 12 日から15年であった

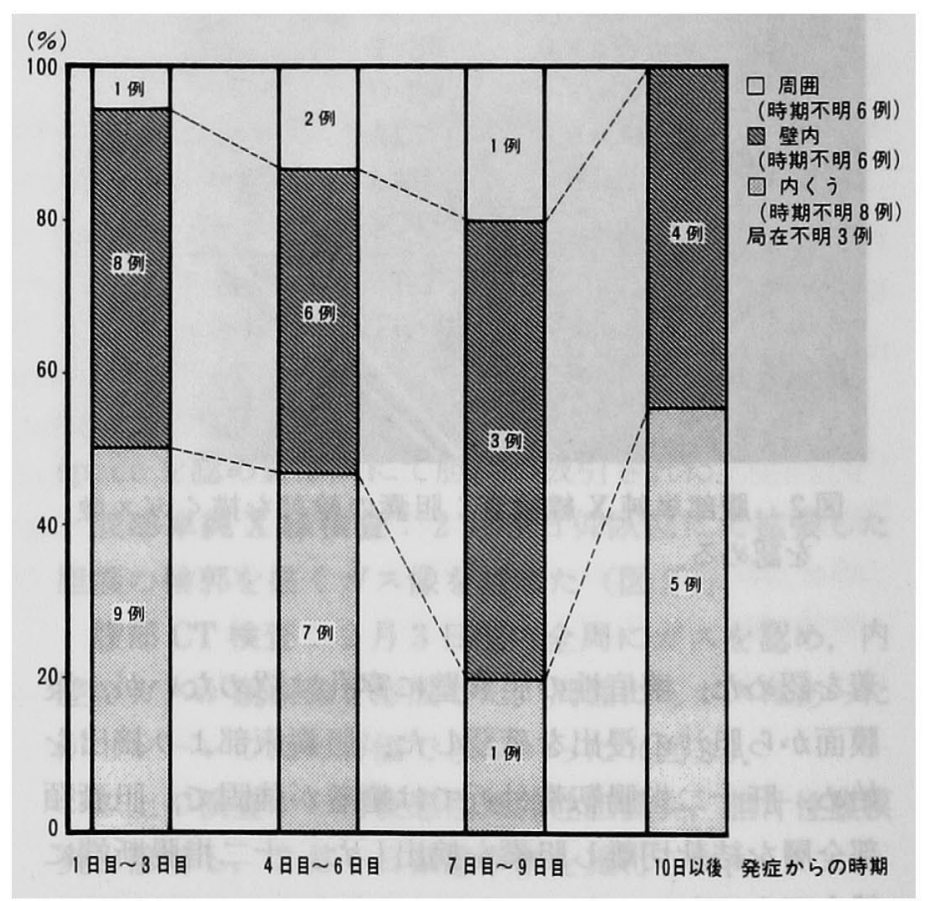

图 5 AEC のガスの局在と発症からの時期：CT 上 ガス像は 4 つの段階に区別できない. 
が, TAE 施行後の 3 例 ${ }^{166117}$ は 3 日，7 日，13日といず れも施行後早期であった。胃手術後12日(無石性)，1 力月 $(\text { 結石の有無不明 })^{3)}, 3$ 力月 $(\text { 無石性 })^{27)}$ といった 術後早期の発症や TAE 後の発症 (有石性 1 例 ${ }^{17}$, 不明 2 (列126)）では，術後胆变炎の病因とされる術後の絶食 と経口再開, 輸血, 胆汁の状態, 麻醉, 脱水, 発熱, 鎮痛薬の使用など34)関与していると考えられた。

\section{（4）AEC と総胆管結石}

AEC K伴う総胆管結石の記載は本邦96例中本例を 含めて12例（全体を96例として13\%）にあったが，こ の5ち 1 例 ${ }^{29}$ は本症発症前である. AEC 発症後の11例 の5ち 4 例1559)133 生胆囊摘出前に診断され同時に総胆 管切開が行われた。 5 例は本例同様胆裹摘出後に結石 を認めたもので，治療として再開腹手術 $(2 \text { 例 })^{4) 5}$, 経 十二指腸的切石 ( 1 例) ${ }^{10}$, 経皮経肝的切石(本例 1 例) が行われ， 1 例51は経過観察された。残る 2 例は AEC も含めて非手術的に経皮経肝的胆鸾穿刺ドレナー

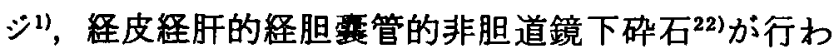
れた。

AECのらち何例に対して術中胆道造影が行われた かは明らかではないが，総胆管切開は胆囊摘出時に上 記 4 例を含む 8 (例1)57) -913)14)に対して施行された。 AEC の高い総胆管結石併存率(11例, 12\%)から，AEC に対する胆雴摘出時に可能であれば術中胆道造影，さ らに疑わしければ総胆管を切開して結石の有無を確認 する必要があると考えられる。

本例は胆要摘出時胆変管からの胆道造影は手技的に 困難であった。 そして CT 検查の再読影では腸瘻閉鎖 術後の 8 月 7 日の撮影で総胆管に結石を認め, 結石成 分はビリルビンカルシゥム石であった。これが遺残結 石か，胆摘後新たにできたものかの判定はできなかっ た。

\section{結 語}

急性気腫性胆桽炎の 1 例を経験したので若干の文献 的考察を加壳て報告した。

\section{文献}

1）矢沢孝文，土屋幸浩，常富重幸他：気腫性胆衰炎の 超音波診断と映像下穿刺治療, 日超音波医会講論 集 $42-A-76: 391,1983$

2）中村 徹, 滕井良介, 原田 大他：急性気瘇性胆衰 炎の 1 治験例，日消病会誌 $81: 304,1984$

3）岡早百合, 金井昌敦, 八重樫寛治他：胃切除後に発 症した気腫性胆塞炎の 1 例, 日臨外会誌 $45: 825$, 1984
4）清家雅彦, 平谷勝彦, 荒木周平他：急性気腫性胆雴 炎の1例, 臨外 $40: 1427-1430,1985$

5）鈴木洋介, 新村建司, 加藤量平：経皮経肝的胆重ド レナージが有用であった急性気腫性胆资の 1 例, 胆と膵 $7: 215-220,1986$

6) Nakamura $\mathrm{H}$, Kondoh $\mathrm{H}$ : Emphysematosus cholecystitis: Complication of hepatic artery embolization. Cardio Intervent Radiol 9: 152 $-153,1986$

7）広田正樹, 福田 稳, 加藤英雄：急性気尰性胆变炎 の 2 例，新渴医誌 $100: 485,1986$

8）寺本 修, 渿原徹, 石川隆一他：気腫性胆赛炎の 1 例. 第 719 回千葉医学会例会(第 1 外科教室談話 会), p117, 1986

9）山口広之, 大曲武正, 橋本茂廣他：急性気腫性胆衰 炎の 1 例, 外科 $49: 317-321,1987$

10）大谷吉明，小笹貴夫，中野末広他：急性気瘇性胆衰 炎の 2 例， 日臨外医会誌 $48: 1143-1147,1987$

11）北村 喬, 森翣, 今村和之他：急性気腫性胆の 5炎の 1 症例，臨と研 $65: 1876-1880,1988$

12）高橋大八郎, 横山 慎, 大沼裕行他：気腫性胆衰炎 の 1 治験例，腹部救急猃療の進歩 8：755-757, 1988

13）奥村 輝, 大貫義則, 宗本義則他：気稙性胆裏炎の 1 例，消外 $11: 641-644,1988$

14）吳山泰進, 岩瀬弘敬, 桐山昌伸他：Pneumobilia を 伴った急性気腫性胆震炎の 1 例，外科診療 30 ： 1163-1166, 1988

15）柳川真一, 吉田和正, 太田慎一他：急性気腫性胆衰 炎の 2 例, 日消病会誌 $85: 146,1988$

16）川村一彦, 藤松利活, 吉森 勝：急性気稙性胆裹炎 の 1 治験例，日臨外医会誌 $49: 1106,1988$

17）场場公寿，横井佳博，坂元隆一他：肝動脈 TAE 後 に発症した気腫性胆衰炎の 1 症例, 日臨外医会誌 $49: 2030,1988$

18）鳥开彰人，末永裕之，鉿木祊一他：急性気腫性胆震 炎の 1 治験例，日消外会誌 $22: 859-862,1989$

19）日野一成，斎藤逸郎，大海庸世他：胆要壁内に多核 巨細胞と好酸球の浸潤を伴った急性気腫性胆衰炎 の1例，日消病会誌 $86: 265-269,1989$

20）児島完治, 津内保彦，松野慎介他：気盾性胆裹炎の 1 例，岡山医学会誌 $101: 53-59,1989$

21）小倉嘉文, 今井俊積, 石田亘宏他：気腫性胆無炎, 肝胆膵 $18: 51-59,1989$

22）井上茂章, 遠藤正章, 清藤 大他：胆石を伴 5 急性 気腫性胆衰炎症例，腹部救急診療の進歩 9: 117 
$-121,1989$

23）永野正史, 藤野 均, 田川一海他：総胆管癌 PTCD 内瘦化治療中に発症した急性気腫性胆露炎の 1 例, 内科 $63: 151-154,1989$

24）久保信之, 伊藤 良, 井上修一：急性気腫性胆震炎 の 1 例, 胆と膵 $10: 1157-1160,1989$

25）大野秀彰, 野田八嗣, 竹森康弘他：胆管内にまでガ ス像の桩がりをみた気腫性胆炎の1例，日消病 会誌 $86: 2255-2259,1989$

26）片岡昭彦, 高橋 学, 櫛田隆久他：気腫性胆衰炎の 1 例, 道南医学会誌 $24: 279-281,1989$

27）倉立真志, 森本重利, 田中直臣他：胃切除啳に発症 した急性気腫性胆露炎の 1 例，臨外 45：645 $-647,1990$

28）豊田 太, 町田浩道, 小島幸次郎地：気腫性胆衰炎 の 1 例，日臨外医会誌 $51: 831,1990$

29）佐尾山信夫，古田 沖，増田 裕他：気腫性胆要炎 の 2 例および本邦 81 例の検討, 日臨外医会誌 $51: 1031-1037,1990$

30) Abengowe CU, McManamon PJM : Acute em- physematous cholecystitis. CMA J 111: 1112 $-1114,1974$

31) Kadir S: X-ray of the month. J Tenn Med Assoc 8: 602-603, 1979

32) Smith RP, Morano J : Acute emphysematous cholecystitis. J MSMA 24 : 128, 1983

33) Heifetz CJ, Wyloge EI : Effect of distension of gallbladder with air and its relationship to acute pneumocholecystitis. Ann Surg 142: 283 $-288,1955$

34) Kasahara $Y$, Umemura $H$, Kuyama $T$, et al: Postoperative acute cholecystitis in Japan. World J Surg 2 : 661-666, 1978

35）佐藤寿雄, 高橋 涉：急性無石胆襄炎の診断之治 療, 外科 $44: 1486-1492,1982$

36) May RE, Strong R: Acute emphysematous cholecystitis. Brit J Surg 58: 453-458, 1971

37）望塚慶次郎, 青柳和彦, 吉野雅武他：術後早期の急 性胆栾炎, 外科 $37: 485-494,1975$

\section{A CASE OF ACUTE EMPHYSEMATOUS CHOLECYSTITIS FOLLOWING GASTRIC RESECTION}

\section{Hideki ABE, Tatsuro WAKAYAMA, Tadaharu OKUYAMA and Tadayuki TOYODA Department of Surgery, Tokyo Metropolitan Hiroo General Hospital}

We describe a patient with acute emphysematous cholecystitis, and with a review of 96 cases previously documented in Japan. A 63-year-old man manifested symptoms 12 days after gastric resection.

The diagnosis of acute emphysematous cholecystitis was established by a plain X-ray film of the abdomen, which showed gallbladder wall filled with air. Cholecystectomy was performed as an emergency procedure. One year after the operation, the patient developed colicky pain at the right hypochondrium. Various examinations revealed stones in the common bile duct and percutaneous transhepatic cholangioscopic lithotripsy was performed.

Out of the 96 cases reported in Japan, 11 cases developed the disease in the postoperatve period after gastric surgery. Three of the 11 occurred in the early period after operation. Another 3 cases occurred after transarotic embolisation for hepatoma, and all these developed soon after the procedure. Stones in the common bile duct were found in 12 out of the 96 cases. 